AN INTRODUCTION TO LINGUISTICS 
Also by Stuart C. Poole

CATALAN IN THREE MONTHS 


\section{An Introduction to Linguistics}

Stuart C. Poole

palgrave 


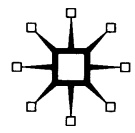

(c) Stuart C. Poole 1999

All rights reserved. No reproduction, copy or transmission of this publication may be made without written permission.

No paragraph of this publication may be reproduced, copied or transmitted save with written permission or in accordance with the provisions of the Copyright, Designs and Patents Act 1988, or under the terms of any licence permitting limited copying issued by the Copyright Licensing Agency, 90 Tottenham Court Road, London W1T 4LP.

Any person who does any unauthorised act in relation to this publication may be liable to criminal prosecution and civil claims for damages.

The author has asserted his right to be identified as the author of this work in accordance with the Copyright, Designs and Patents Act 1988.

Published by

PALGRAVE

Houndmills, Basingstoke, Hampshire RG21 6XS and 175 Fifth Avenue, New York, N. Y. 10010

Companies and representatives throughout the world

PALGRAVE is the new global academic imprint of St. Martin's Press LLC Scholarly and Reference Division and Palgrave Publishers Ltd (formerly Macmillan Press Ltd).

DOI 10.1007/978-1-349-27346-1

This book is printed on paper suitable for recycling and made from fully managed and sustained forest sources.

A catalogue record for this book is available from the British Library.

\section{9}

11

Typeset by Forewords, Oxford/Longworth Editorial Services Longworth, Oxfordshire 


\section{Contents}

Preface

viii

1 What Is Language?

1.1 The Significance of Language

1.2 What Is Language?

1.3 The Functions of Language

1.4 What Is a Language?

1.5 The Elements of Language 6

$\begin{array}{ll}\text { Summary } & 7\end{array}$

$\begin{array}{lr}\text { Exercises } & 8\end{array}$

2 Lexis 9

2.1 What Is a Word? 9

2.2 Where Do Words Come From? 12

Summary 20

Exercises $\quad 20$

3 Semantics 21

3.1 The Function of Lexemes 21

3.2 The Meaning of Meaning 22

3.3 Semantic Range 22

3.4 The Definition of Semantic Range 24

3.5 Collocation and Idiom 28

3.6 Homonymy and Polysemy 30

3.7 The Human Element of Meaning 31

3.8 Pragmatics 33

3.9 Discourse Analysis 37

Summary $\quad 38$

Exercises $\quad 39$

4 Phonetics 41

4.1 The Organs of Speech 41

4.2 Consonants 43

4.3 Phonemic Notation 47 
$\begin{array}{lll}4.4 & \text { Vowels } & 49\end{array}$

4.5 Sounds in Sequence $\quad 52$

Summary $\quad 53$

Exercises $\quad 53$

5 Phonology 55

5.1 Sound Systems of Languages $\quad 55$

5.2 The Phoneme 56

5.3 Phonological Rules $\quad 57$

5.4 The Phonology of English 58

5.5 The Phonology of Other Languages 62

$\begin{array}{lll}5.6 & \text { Suprasegmental Features } & 66\end{array}$

$\begin{array}{ll}\text { Summary } & 70\end{array}$

$\begin{array}{ll}\text { Exercises } & 70\end{array}$

6 Morphology 73

6.1 The Composition of Words 73

$\begin{array}{lll}6.2 \text { Morphemes } & 75\end{array}$

6.3 Derivation and Inflection $\quad 75$

$\begin{array}{lll}6.4 & \text { Productivity and Word Formation } & 77\end{array}$

6.5 Problems of Morphological Analysis 78

$\begin{array}{ll}\text { Summary } & 81\end{array}$

$\begin{array}{ll}\text { Exercises } & 81\end{array}$

7 Syntax $\quad 83$

7.1 Syntax as Opposed to Morphology 83

$\begin{array}{llr}7.2 & \text { Word Classes } & 84\end{array}$

$\begin{array}{lll}7.3 & \text { Constituent Structure } & 86\end{array}$

$\begin{array}{lll}7.4 & \text { Noam Chomsky } & 89\end{array}$

$\begin{array}{lll}7.5 & \text { Syntactic Forms } & 91\end{array}$

Summary $\quad 93$

Exercises $\quad 94$

8 Regional Variation 96

8.1 Variations of Variations 96

8.2 Horizontal Definition of Dialect 98

8.3 Vertical Definition of Dialect 102

8.4 The Nature of Variation 105

$\begin{array}{ll}\text { Summary } & 107\end{array}$

$\begin{array}{ll}\text { Exercises } & 108\end{array}$

9 Social Variation 109

9.1 The Social Dimension 109

9.2 The Standard Language 111 
9.3 The Urban Vanguard 112

9.4 Men and Women 113

9.5 Power and Solidarity 114

9.6 Registers and Diglossia 116

9.7 Taboo and Political Correctness 118

$\begin{array}{lll}9.8 \text { Slang } & 120\end{array}$

Summary $\quad 121$

$\begin{array}{ll}\text { Exercises } & 121\end{array}$

10 Historical Linguistics 123

10.1 The Diachronic Dimension 123

10.2 How Language Changes 124

10.3 Why Language Changes 129

10.4 When Language Changes 134

$\begin{array}{lll}10.5 & \text { Divergence } & 135\end{array}$

$\begin{array}{ll}10.6 \text { Convergence } & 139\end{array}$

10.7 Pidgins and Creoles 141

Summary $\quad 142$

Exercises $\quad 143$

11 The Languages of Western Europe 145

11.1 The Indo-European Family of Languages 145

11.2 The Germanic Languages 146

11.3 The Romance Languages 154

11.4 The Celtic Languages 162

$\begin{array}{lll}11.5 & \text { Finnish } & 164\end{array}$

Summary $\quad 164$

Texts 165

$\begin{array}{ll}\text { Exercises } & 174\end{array}$

12 Writing Systems 177

12.1 Communication across Time and Space 177

12.2 Morphemic and Phonetic Script 178

12.3 Chinese Script - A Morphemic System 181

12.4 Roman Script - An Alphabetic System 182

$\begin{array}{ll}12.5 \text { Allographs } & 184\end{array}$

Summary $\quad 185$

$\begin{array}{ll}\text { Exercises } & 185\end{array}$

Glossary 186

Guide to Exercises 198

Bibliography 207

Index 211 


\section{Preface}

This book introduces the nature of language. It deals with the sounds that we make when we speak, with the way in which we construct sentences, with the ways in which our speech varies between social situations, and so on. It does so by the commonly adopted method of having chapters with such headings as phonetics, syntax, social variation. Less conventionally, it has a major chapter which, against the background of these aspects of linguistics, presents the principal features of the languages of western Europe.

You have at least one remarkable skill; you can speak a language. For at least one language you generally know what can and what cannot be designated by the everyday words, you know what is and what is not an acceptable way of combining words to form a sentence, you have a good idea of whether or not a particular statement would be acceptable in a particular social situation. As a skilled user, then, you already have a substantial foundation for the study of language. That foundation and an interest in language are all you need; given those, this introductory book can lead you to an understanding of what language consists of, of how it works. It serves as an introductory book for students of linguistics and as important background material for students of modern languages. Reflecting my work in continuing education, I have attempted to write in a readable style that will also make the book attractive to the many people who want to explore the fascinating world of language without entering full-time education.

I would like to thank my wife Beryl and a student, Arthur McIvor, for taking time to read and comment on my draft. I also thank Beryl for her support and tolerance while I was working on the book. I also thank Arthur as a representative of those students whose interest and enthusiasm help to inspire and reward my work. The facilities of the University of Edinburgh such as the library and word-processing facilities have been of great assistance. 